\title{
Study of Some Markers of Oxidative Stress Statues in Cardiovascular Disease Patients
}

\author{
Yasmeen Muhialdeen H., Alaa H. Jawad and Wisam Kadhum H. Al-Hashemi \\ Department of Chemistry, College of Science, Al-Nahrain University, Baghdad-Iraq.
}

\begin{abstract}
The oxidative stress is one of the main cause for cardiovascular diseases and also one of the results of these diseases, its development. The aim of this study was to investigate the relationship between of some oxidative stress markers and cardiovascular diseases. This study involved 84 samples matched ages and sex divided into groups; 28 samples cardiovascular and 28 hypertensive in addition to 28 healthy control group. The following analysis were done: lipid profile, malondialdehyde (MDA), and albumin. The results show there is a significant increase in lipid profile between each group and control group. MDA was significantly higher in patients compared to controls whereas no significant difference was found in albumin between patient and control groups. The increase in MDA which is a product of lipid peroxidation is attributed to destruction in body cell caused by free radicals and resulting oxidative stress. It has been concluded that the assessing the lipid ratios is important even in a normal individual as it is one of the factors for development of cardiovascular diseases and their complications. There is a positive relation between oxidation results from these diseases and their developments.
\end{abstract}

Keywords: Hypertension, Cardiovascular, Malondialdehyde, Reactive oxygen species.

\section{Introduction}

Blood pressure is a measure of the force that the circulating blood exerts on the walls of the main arteries [1], macrophages had been assumed to be the source of the most ROS in the vessel's wall, However, it has become clear that virtually all the cells in the vessel wall produce ROS in different amounts and in response to diverse stimuli [2]. Cardiovascular is a pathological condition interrelated with cardiac valves, Oxidative stress promotes vascular smooth muscle cell proliferation and hypertrophy and collagen deposition, leading to thickening of the vascular media and narrowing of the vascular lumen. It has been shown that mechanical stretch to vessel wall induces ROS release, this suggests the possibility that high blood pressure itself increases ROS independent of renin angiotensin system activity [3]. In addition, increased oxidative stress may damage the endothelium and impair the endotheliumdependent vascular relaxation and increases vascular contractile activity [4]. Reactive oxygen species (ROS) are highly reactive intermediates of the oxygen metabolism, which are constantly being generated and destroyed. ROS may originate from both exogenous and endogenous sources [5].
Exogenous sources include environmental agents, radiation, therapeutic agents, and tobacco smoke. Endogenous sources include mitochondria, peroxisome and inflammatory cell activation [5]. When there is an imbalance between the generation of ROS and the antioxidant defense system so that the latter becomes overwhelmed, oxidative stress occurs [2]. Oxidants and free radicals are inevitably produced during most physiological and metabolical processes, and the human body has defensive antioxidant mechanisms, these mechanisms vary according to the cell and tissue type and they may act antagonistically or synergistically [6]. Oxidative stress has beenimplicated in a wide variety of disease processes includingatherosclerosis, diabetes, pulmonary fibrosis, neurodegenerative disorders, and arthritis, and is believed to be a major factor in aging [7]. In physiological conditions, lowlevels of ROS play a protective role in the organism, while increased generation of free radicals is associated with tissue or DNA damage [8]. The lipid profile is a group of tests that are often ordered together to determine the risk of heart disease. These tests are good indicators of whether someone is likely to have a heart attack or stroke caused by the blockage of blood vessels or hardening 
of the arteries. The lipid profile, Total cholesterol high levels of cholesterol in blood circulation are strongly associated with progression of heart disease [9].Several studies have implicated impaired lipid metabolism as one of the crucial factors in the development of this disease [5,9] observed significantly higher total cholesterol (TC) and triglyceride (TG) levels and lower high-density lipoprotein cholesterol (HDL) in cardiac patients[10]. Malondialdehyde (MDA) is an end-product of the radical-initiated oxidative decomposition of polyunsaturated fatty acids; therefore, it is frequently used as a biomarker of oxidative stress [11], a studyby Ramprasad 2014 [12] recorded a significant increase in MDA values in cardiac patients and Tripti et al. 2013 observed an increase in MDA with hypertension [13]. Malondialdehyde, in fact, is not only an end-product of lipid peroxidation, but also the oxidative product of amino acids, carbohydrates, and DNA [14]. Albumin represents the most abundant protein in thecirculatory system with a significant antioxidant activity [15], the antioxidant activity of albuminresult from its ability to bind bilirubin, homocysteineand lipids [16]. Several observational studies did not find an association between serum albumin and CVD. It has been suggestedthat the relation between serum albumin and CHD may vary across sex, age, and level of serum cholesterol. Corti andcolleagues found an association between serum albuminand CVD among older women but not among older men [17].

\section{Materials and Methods}

The present study comprised 84 women [namely control (28), hypertensive (28) and cardiovascular diseases (28)] aged between 25-60 years. These patients were hospitalized at educational laboratories in the Ibn Alnafese hospital. They were divided into groups of healthy as control group, hypertensive and cardiovascular diseasedpatients. Blood sample were collected and centrifuged at $[4000 \mathrm{xg}]$ for 5 min after clotting. The resultant serum were separated and stored at $[-40]^{\circ} \mathrm{C}$ until used. Serum lipid profile was measured as follows: the serum cholesterol and triglyceride and High density lipoprotein was measured using kits supplied by Randox company. Estimation of serum albumin was done using kit provided by BioSystems company. Friedwald equationused to estimate LDL-cholesterol

$[$ LDL-Chol $]=[$ Total Chol $]-[$ HDL $]-[$ VLDL $]$

Serum malondialdehide MDA is typically quantified from plasma samples with the mostpopular method being a colorimetric assay based on the reactionbetween MDA and thiobarbituric acid (TBA) described by Shah and Walker[18].

\section{Statistics}

The Statistical Analysis System-SAS (2012) was used to determine of different factors in studied parameters, P-value used to significant compare between means in this study.

\section{Results and Discussion}

Eighty four sample subjects comprising of 56 patients and 28 healthy were included in the present study, Table (1) shows the means and standard deviation of age, body mass index (BMI), cholesterol, triglyceride , high density lipoprotein (HDL), malondialdehyde (MDA) in addition to albuminlevels for the control and patients groups. 
Table (1)

Characteristics of the Hypertension (HT) and control group (mean $\pm S D)$.

\begin{tabular}{|l||c|c|c|}
\hline \multicolumn{1}{|c||}{ Characteristic } & $\begin{array}{c}\text { HT patient group } \\
\mathbf{N = 2 8}\end{array}$ & $\begin{array}{c}\text { Control group } \\
\mathbf{N = 2 8}\end{array}$ & P value \\
\hline \hline Age $($ year) & $46.8 \pm 8.2$ & $43.4 \pm 9.3$ & $>0.1$ \\
\hline \hline BMI $\left(\mathrm{kg} / \mathrm{m}^{2}\right)$ & $31.48 \pm 0.95$ & $27.27 \pm 0.97$ & $<0.05$ \\
\hline Cholesterol mmol/L & $5.2 \pm 0.9$ & $4.23 \pm 0.24$ & $<0.01$ \\
\hline Tri glyceridemmol/L & $2.4 \pm 1.03$ & $1.31 \pm 0.09$ & $<0.05$ \\
\hline HDL mmol/L & $1.1 \pm 0.4$ & $1.42 \pm 0.09$ & 0.01 \\
\hline LDLmmol/L & $4.13 \pm 1.2$ & $3.53 \pm 0.17$ & $<0.01$ \\
\hline LDL/HDLmmol/L & $4.3 \pm 1.2$ & $2.83 \pm 0.24$ & $<0.05$ \\
\hline MDA $\mu \mathrm{mol} / \mathrm{L}$ & $6.35 \pm 0.71$ & $3.31 \pm 0.26$ & $<0.01$ \\
\hline \hline Albumin $\mathrm{g} / \mathrm{L}$ & $35.52 \pm 1.84$ & $44.18 \pm 2.20$ & $<0.01$ \\
\hline
\end{tabular}

Data in Table (2) show that there are high significant differences in mean value of cholesterol, triglyceride and malondialdehyde for patients group in comparison with control group, and as shown in same table the albumin was highly significantly decreasedin the patient compared withcontrol mean values (group).

Table (2)

Characteristics of the Cardiovascular diseases and control group (Mean $\pm S D)$.

\begin{tabular}{|c|c|c|c|}
\hline Characteristic & $\begin{array}{c}C D V \cdot \text { patient group } \\
N=28\end{array}$ & $\begin{array}{c}\text { Control group } \\
N=28\end{array}$ & $P$ value \\
\hline Age (year) & $52.3 \pm 9.3$ & $43.4 \pm 9.3$ & $>0.1$ \\
\hline BMI $\left(\mathrm{kg} / \mathrm{m}^{2}\right)$ & $32.59 \pm 6.36$ & $31.4 \pm 4.85$ & $<0.05$ \\
\hline Cholesterol mmol/L & $4.62 \pm 0.25$ & $4.23 \pm 0.24$ & $<0.01$ \\
\hline Triglyceridemmol/L & $2.209 \pm 0.17$ & $1.31 \pm 0.09$ & $<0.01$ \\
\hline HDL mmol/L & $1.15 \pm 0.06$ & $1.42 \pm 0.09$ & $<0.01$ \\
\hline LDLmmol/L & $4.13 \pm 0.23$ & $3.53 \pm 0.17$ & $<0.05$ \\
\hline LDL/HDLmmol/L & $3.86 \pm 0.29$ & $2.83 \pm 0.24$ & $<<0.01$ \\
\hline $\mathrm{MDA} \mu \mathrm{mol} / \mathrm{L}$ & $5.49 \pm 0.94$ & $3.31 \pm 0.26$ & $<<0.01$ \\
\hline Albumin g/L & $35.49 \pm 1.47$ & $44.18 \pm 2.20$ & $>0.01$ \\
\hline
\end{tabular}

The significant difference $(\mathrm{p}<0.05)$ in lipid profiledue to cholesterol plaque causes the muscle cells to enlarge and form a hard cover over the affected area. This hard cover is what causes a narrowing of the artery, blood flow will be reduced and increasing blood pressure. Plaques are covered with a fibrous cap and it creates a bump on the artery wall of hypertension patients. Decreased HDL-C in patients indicates decreased rate of reverse cholesterol transport and therefore accumulation of $\mathrm{TG}$ rich lipoproteins leading to increased risk of atherosclerosis and CVD in all groups. The LDL lipoprotein increase atherogenicity and available data suggest that LDL is more atherogenic than other lipoproteins. CVD have been generally described as having high levels of oxidative stress. And this agree with other studies $[19,10]$.

The LDL/HDL cholesterol ratio appears to be as useful as the total/HDL cholesterol ratio. 
Their similarity can be explained by the fact that approximately two thirds of plasma cholesterol are found in LDL and, consequently, total and LDL cholesterol are closely relatedthe significant difference between risk factor ratio (LDL/HDL) is also found by (Millan J. et al 2009) [20] who found the LDL/HDL cholesterolratio was a powerful predictor of cardiovascular risk.

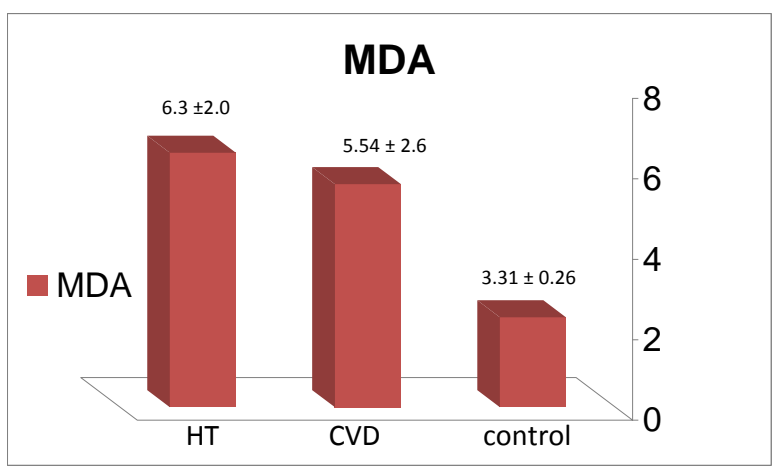

Fig. (1) Mean conc. ( $\mu$ mol/L) of oxidative marker MDA for studied groups.

The highly significant difference $(\mathrm{p}<0.01)$ of MDA in CV patient may due to high oxidative stress which generally causes damage to the membrane polyunsaturated fatty acids leading to the generation of MDA. This result agree with study of (Jawalekar S. et al 2010) [21].

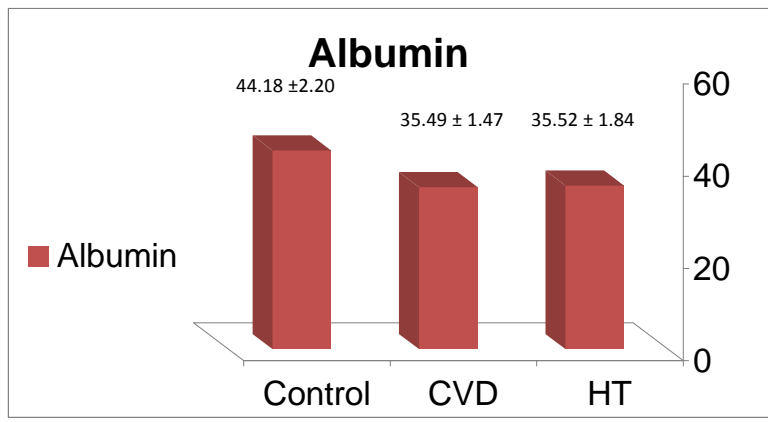

Fig. (2) Mean conc. (g/L) of albumin in the studied groups.

Albumin contains a free sulfhydryl group, this forms a disulfide with several compounds like cysteine, homocysteine, or glutathione, Albumin is able to scavenge hydroxyl radicals [22], the decrease in albumin in patient is agreed with results of (Durga V. et al 2014) [23] who suggested that result is may be due to its function as antioxidant activity so the nonoxidized albumin is decrease in addition to negative acute phase protein, so inflammation is considered the principle cause of a decrease in the serum albumin [22]. The weak negative correlation $(\mathrm{r}=-0.1)$ between MDA and albumin in cardiovascular disease patient and control group agreedwith (Al Fartosi k. et al. 2010) who found a negative correlation between MDA and Albumin [24]. There is an evidence for a significant antioxidant activity of the represent the major and predominant circulating antioxidant in plasma known to be exposed to continuous oxidative stress. There was no correlation between BMI and MDA and this agree with (Ali P. et al 2008) [25].

A positive correlation observed between MDA and LDL- cholesterol and this result also shown by (Venkata Rao et al 2011) and (Ogunro P. et al 2009) [26,27].

\section{Conclusion}

Based on result of this study it may be concluded that the importance of assessing the lipid ratios even in a normal individual as it is one of the factors for development of cardiovascular diseases and there is a positive relation between oxidation results from cardiovascular and hypertension diseases and their developments.

\section{Acknowledgements}

The authors would like to thank Al-Nahrain University and Ibn-Alnafese hospital for the financial supports and research facilities.

\section{References}

[1] Caroline M.; "Introduction to Epidemiology: Distribution and Determinants of Disease"; Cengage Learning 6, 302-303, 2013.

[2] Ahmad A., Singhal U., Mohd M., Islam N., Rivisi I.; "The Role of the Endogenous Antioxidant Enzymes and Malondialdehyde in Essential Hypertension"; Journal of Clinical and Diagnostic Research, 7,987990; 2013.

[3] Yasunobu H. and Hiroshi S., "Hypertension and Oxidative Stress"; the Journal of the Japan Medical Association, 124, 1575-1579, 2000.

[4] Dhananjay V. Bhale, Manjusha D Hivre, Roshan K., Aasiya S., Devendra M., Ashlesha B. "Study of Oxidative Stress in Patients with Hypertension"; International J. 
of Recent Trends in Science And Technology, 9, 157-158,2013.

[5] Shiv K.; "Free Radicals and Antioxidants: Human and Food System"; Advances in Applied Science Research, 2, 129-135,2011.

[6] José A.; "Oxidative Stress and Chronic Degenerative Diseases-a Role for Antioxidants"; Janeza Trdine, 9,34-35,2013.

[7] Poljsak B. and Milisav I.; "The Neglected Significance of Antioxidative Stress, a Review"; Oxidative Medicine and Cellular Longevity, 1-12,2012.

[8] Thomas B., Anastassiya B., Polycarpos P., Alexandros G. Georgakilas; "Role of oxidative stress and DNA damage in human carcinogenesis"; Mutation Research, 711, 193-201, 2011.

[9] Hasan R., Ahmad M., Aisha J., Zaka F.; "A study on the variations in lipid profile of valvular heart disease patients"; Int J Biol Med Res., 4 , 3414 - 3418, 2013.

[10] Khan H. A., Alhomida A. and SobkiS. H.; "Lipid Profile of Patients with Acute Myocardial Infarction and its Correlation with Systemic Inflammation"; J. Biomarker Insights, 8, 1-7, 2013.

[11] YangT., Yi-Jie C., Shwu-Fen C., ChuHuang C., Po-Yuan C., and Shao-C.;" Malondialdehyde mediates oxidized LDLinduced coronary toxicity through the AktFGF2 pathway via DNA methylation"; Journal of Biomedical Science, 21, 1-12, 2014.

[12] Ramprasad N.; "Study of trace elements and malondialdehyde levels incardiovascular disease patients"; Int. J. Adv. Res. Biol. Sci., 1, 25-32, 2014.

[13] Tripti S., Agarwal B., Sharma V., Sabiha N. and Pooja L.; "Paraoxonase Activity in Prehypertension and its Relation to Oxidative Stress"; Biomedical and Pharmacology J,6, 389-394, 2013.

[14] Jiangang L., Changsheng L., Lijuan S., Hongxiang G., Jiankang L.; "Neuronal Mitochondrial Toxicity of Malondialdehyde: Inhibitory Effects on Respiratory Function and Enzyme Activities in Rat Brain Mitochondria"; Neurochem Res, 34, 786794, 2008.

[15] Faure P., Tamisier R., Baguet J-P., Favier A, Halimi S., Le'vy P., and Pe'pin J-L.; "Impairment of serum albumin antioxidant properties in obstructive sleep apnoea syndrome"; Eur Respir J, 31,1046-1053, 2008.

[16] Taverna M., Anne-Lise M., Jean-Paul M. and Bertrand G.; "Specific antioxidant properties of human serum albumin, a Review"; Annals of Intensive Care 3, 1-7, 2013.

[17] Luc D., Kenneth J., Adrienne L., Daniel L. and Curtis E. ;"Serum Albumin and Risk of Myocardial Infarction and All-Cause Mortality in the Framingham Offspring Study"; J of American Heart Association, 106, 2919-2924, 2002.

[18] Shah S., Walker P., "Evidence suggesting a role for hydroxyl radical in glycerolinduced acute renal failure"; American J of Physiology, 255, 438-443, 1988.

[19] Mohsen M., Ahmed I., Khaldoon S., Mona A.; "Lipid profile in Egyptian patients with coronaryartery disease"; The Egyptian Heart J.,65, 79-85, 2013.

[20] MillanJ., Xavier P., Anna M., Manuel Z., Joan R., Ascaso F., Luis M., Alipio M., Mijares A. H., Pedro G., Juan F A., Juan P.; "Lipoprotein ratios: Physiological significanceand clinical usefulness in cardiovascular prevention"; J Vascular Health and Risk Management, 5, 757-765, 2009.

[21] Jawalekar S. L. J., Ujjwala J., Vasant T., Deshmukh Y. A.; "Status of Lipid profile, MDA and protein carbonyl in patients with cardiovascular diseases"; Archives of Applied Science Research, 2, 8-14, 2010.

[22] Marjolaine R., Philippe R., Nihar R., Evelyne T., Emmanuel B.; "The antioxidant properties of serum albumin, Review"; FEBS Letters, 582, 1783-1787, 2008.

[23] Durga V. P., Shabana S.,. RamanaG. V, Shalini T. G.; "Assessment of Copper, Ceruloplasmin, Total Proteins and Albumin in Gestational Hypertension"; IOSR J of Dental and Medical Sciences, 13, 101-104, 2014.

[24] Al-Fartosi K., Al-Salih R., Salih J.; "Study of relationship between blood parameters and oxidant-antioxidant status of patients with unstable angina pectoris and myocardial infractions"; Thi-Qar Medical J. 4,47-64, 2010. 
[25] Ali P., Nemati A., and Naghizadeh A.; "Serum MDA as a Diagnostic`s Biomarker in Stable Coronary Heart Disease"; Research J of Biological Sciences, 3,206210, 2008.

[26] Venkata R., Ravi K.; "Evaluation of correlation between oxidative stress and abnormallipid profile in coronary artery disease"; J. of Cardiovascular Disease Research, 2, 57-60,2011.

[27] Ogunro P., Balogun W., Fadero F., Idogun E., Oninla S., Elemile P., Eziyi A.; "Plasma Lipid Peroxidation and Total Antioxidant Status among Dyslipidaemic and Hypertensive Nigerians with High Risk of Coronary Heart Disease"; West African J. of Medicine, 28, 87-91, 2009.

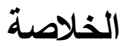

الجهـ التاكســي هـو احــ الاسـباب الرئيسية لامـراض

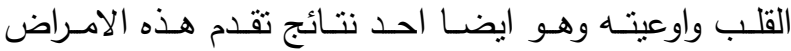

والتحطم الناتج منها. هدف هذه الدراسة هو بحث العلاقة بين مؤشرات الجهد التاكسدي وامراض القلب واوعيته. هذه الدراسة

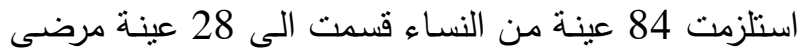
بامراض القلب واوعيته و 28 بأمراض ضغط الدم بالإضافة الى 28 من الاصـحاء كمجموعة سيطرة. التحليلات التاليـة اجريت لكل العينـات: صسورة الدهون، المسالون داي الديهايد،

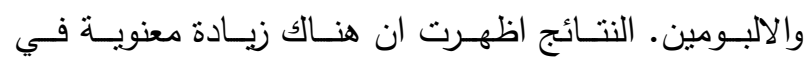
مستويات صورة الدهون بين كل مجموعة ومجموعة السبطرة. المالوندايالديهايـد اعلى بشـل معنـوي في المرضـى مقارنـة

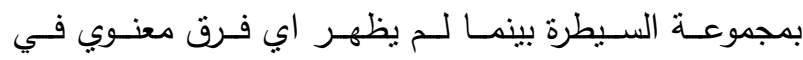

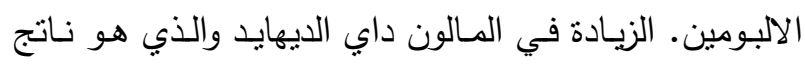
فوق اكسدة الدهون يعزى الى التحطم في خلايا الجسم بسبب التبادي

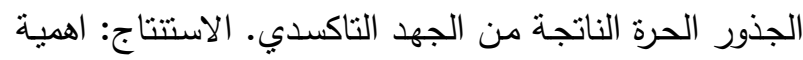

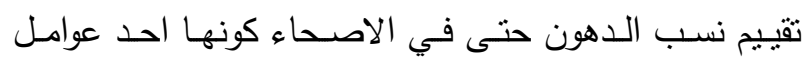
تطور امراض القلب واوعيته وتعقيداته. هذه العلاقة الموجبة بين الاكسـدة الناتجـة مـن هذه الامـراض وتفاقمهـا. وبالتـالي يقترح زيادة تتاول مضـادات الاكسدة للحد من هذه الامراض هـ لهن 